\title{
Tropical storms trigger phytoplankton blooms in the deserts of north Indian Ocean
}

\author{
J. Kuttippurath (iD ${ }^{1 凶}$, N. Sunanda ${ }^{1}$, M. V. Martin ${ }^{2}$ and Kunal Chakraborty $\mathbb{D}^{3}$
}

As the phytoplanktons consume carbon dioxide, they significantly influence the global carbon cycle and thus, the global temperature by modifying sea surface temperature. Studies on the changes in chlorophyll-a (Chl-a) amount are therefore, key for understanding the changes in ocean productivity, global carbon budget and climate. Here, we report the cyclone-induced Chl-a blooms in the North Indian Ocean (NIO) using the ocean colour measurements from satellites for the past two decades (1997-2019). The average Chl-a concentration associated with cyclone-induced phytoplankton blooms is around $1.65 \mathrm{mg} / \mathrm{m}^{3}$, which is about $20-3000 \%$ higher than the average open ocean or pre-cyclone Chl-a levels, depending on the cyclones. In general, the phytoplankton bloom is inversely related to the translational speed (TS) of cyclones, as slower storms make intense Chl-a blooms. In addition to wind-induced upwelling and TS of cyclones, cold-core eddies also play a major role in enhancement of $\mathrm{Chl}$-a when the cyclones encounter eddies on their track. It is observed that the cyclone-induced phytoplankton blooms are larger in the La Niña years than that in the El Niño and normal years. The amplitude of bloom is higher for the positive IOD years in Bay of Bengal, but for negative IOD years in Arabian Sea. Henceforth, this study provides new insights into the life cycle, seasonal changes, and magnitude of the cyclone-induced primary production, remote forcing and greenhouse mediated climate change in NIO.

npj Climate and Atmospheric Science (2021)4:11; https://doi.org/10.1038/s41612-021-00166-x

\section{INTRODUCTION}

Tropical cyclones (TCs) are extremely destructive weather events that occur over warm ocean waters in the tropics, and they can initiate entrainment and upwelling in the ocean. The pre-existing disturbances in the atmosphere, warm sea surface temperatures (SST) above $27^{\circ} \mathrm{C}$, prevailing instability in the atmosphere and lower vertical wind shear are some of the criteria for the formation of TCs. The two seasons in which cyclones primarily occur over the North Indian Ocean (NIO) are the pre-monsoon (March, April and May) and post-monsoon (October, November and December), and Bay of Bengal (BoB or the bay) experiences about $7 \%$ of the total annual TCs occur worldwide ${ }^{1}$. Cyclonic activity is mainly restricted to May-June in the pre-monsoon and October-November in the post-monsoon seasons over the Arabian Sea (AS) ${ }^{2}$. NIO, consisting of $B o B$ and $A S$, is one of the conducive regions in the world for TC activity. Although BoB and AS have many similarities, there are significant differences, such as the reversal of winds during the monsoon seasons. In addition, precipitation transcends evaporation in $\mathrm{BoB}^{3,4}$, whereas evaporation exceeds precipitation in $\mathrm{AS}^{5,6}$. Besides, the large fresh water influx in the form of oceanic precipitation $^{7}$ and river run off ${ }^{8,9}$ play crucial roles in dynamical processes in $\mathrm{BoB}$, which also make salinity lower in BoB than in AS. The strong stratification in BoB further affects its physical, chemical and biological processes ${ }^{10-12}$.

The bay is a low productive oceanic basin due to intense stratification produced by huge river water influx, whereas AS is a biologically high productive region. Riverine input brings in nutrients that are usually lost to deeper depths due to its narrow continental shelf ${ }^{13,14}$. However, the TC events can upwell the subsurface waters due to the stress exerted by winds on the surface and supplement nutrients to the shoal sunlit zone, and thus, escalate phytoplankton yield ${ }^{15-18}$. The frequency of cyclone occurrence in $\mathrm{BoB}$ is higher during post-monsoon ${ }^{19}$ as the absence of upper level jet streams lead to low vertical wind shear there. On the other hand, heavy rainfall and huge fresh water influx during south west monsoon lead to development of a Barrier Layer $(\mathrm{BL})^{20}$, which persists throughout the post-monsoon season, and inhibits mixing and limits upwelling during the cyclone events in BoB $^{21}$. Satellite measurements of the Tropical Rainfall Measuring Mission (TRMM) show that the pre-monsoon cyclones in NIO can make an SST drop of up to $3^{\circ}$, although the strongest cyclones that occurred in the post-monsoon did not significantly cool the northern BoB SST due to the strong stratification there ${ }^{2}$. Apart from these, tropical cyclones also alter the carbon cycle. For instance, Dahal et al. ${ }^{22}$ examined the tropical cyclones that occurred from 1900 to 2011 in the United States to understand the influence of cyclonic activity on aboveground biomass mortality.

Although there are studies on Chl-a enhancement during the passages of different cyclones over BoB, most studies are dedicated to single cyclone events in different years and wherefore, the differences in bloom occurrences and the physical mechanisms behind the events are not completely known. For example, the effect of Orissa Super Cyclone (1999) on Chl-a off the coast was analysed by Nayak et al. ${ }^{23}$ using Ocean Colour Monitor (OCM) observations. Vinayachandran and Mathew ${ }^{18}$ used Sea-Viewing Wide Field-of-View Sensor (SeaWiFS) data to analyse the $\mathrm{Chl}-\mathrm{a}$ bloom associated with the northeast monsoon and selected cyclones in 1996-2001. Patra et al. ${ }^{24}$ examined the contrasting $\mathrm{Chl}-\mathrm{a}$ abundance in $\mathrm{BoB}$ associated with the cyclones BOB05 (1999), BOB06 (1999) and BOB05 (2000) using SeaWIFS data. Sarangi et al. $^{25}$ used Indian Remote Sensing satellite (IRS-P4) OCM measurements and found that cyclone-induced upwelling is the primary cause of elevated Chl-a during the

${ }^{1}$ CORAL, Indian Institute of Technology Kharagpur, Kharagpur, India. ${ }^{2}$ National Institute of Ocean Technology, Ministry of Earth Sciences, Chennai, India. ${ }^{3}$ Indian National Centre for Ocean Information Services, Ministry of Earth Sciences, Hyderabad, India. ${ }^{\circledR}$ email: jayan@coral.iitkgp.ac.in 
BOB05 and BOB06 events in 1999 there. Rao et al. ${ }^{26}$ analysed the impact of cyclone BOB05 (2000) and found an enhancement of $\mathrm{Chl}-\mathrm{a}$ in the post-cyclone period using the OCM data. Vidya et al. $^{21}$ examined the contrasting response of $\mathrm{Chl}-\mathrm{a}$ with two cyclones, Thane (2011) and Phailin (2013), using the Moderate Resolution Imaging Spectrometer (MODIS) measurements. Chacko $^{27}$ showed that there was twice the Chl-a amount in the post-cyclone phase than that in the pre-cyclone stage of Hudhud, as analysed from the MODIS data. Chacko ${ }^{28}$ has examined the relationship between translational speed and biological production induced by selected cyclones in NIO.
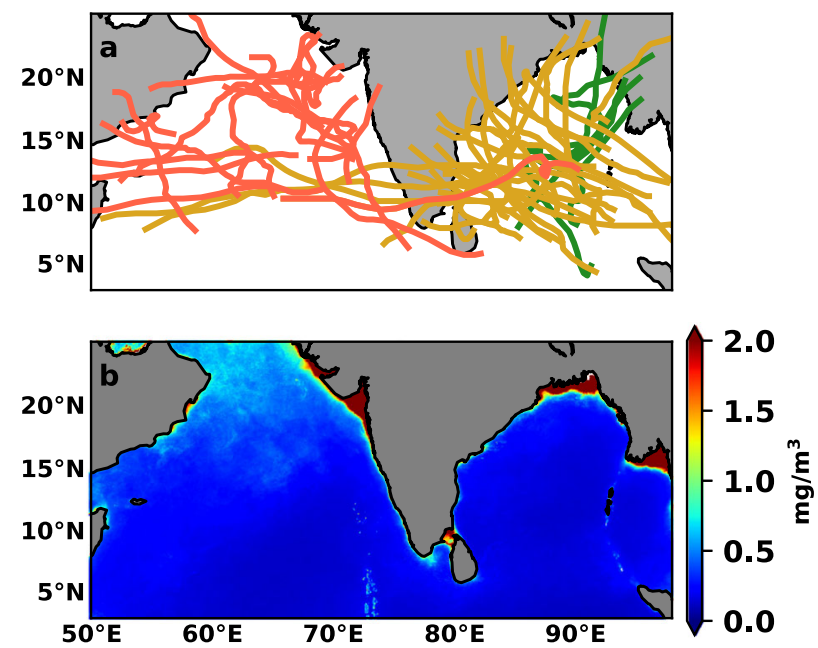

Fig. 1 The cyclone tracks and pre-cyclone background Chl-a value. a The study region North Indian Ocean (NIO) and the tracks for the pre- (green) and post-monsoon (yellow) cyclones for BoB and AS (red), as analysed for all cyclones occurred during the study period (1997-2019).
Subramanyam et al. ${ }^{29}$ demonstrated that $\mathrm{Chl}$-a increased up to $5-8 \mathrm{mg} / \mathrm{m}^{3}$ after the passage of cyclone ARB01 in 2001. Similarly, the model simulations of Chakraborty et al. ${ }^{30}$ showed significant enhancement of Chl-a after the passage of cyclones ARB01 (2001), Gonu (2007) and Phyan (2009) in AS. Pan et al. ${ }^{31}$ showed the role of wind forcing and selected oceanic parameters on phytoplankton blooms in the northwest Pacific and South China Sea. The above-mentioned studies suggest that the intensity of cycloneinduced phytoplankton bloom depends on several factors. As stated previously, most of these studies focussed on one or a few cyclone events in BoB or AS. Therefore, a comprehensive analysis of all cyclones occurred during the satellite era (since 1997) in both basins of $\mathrm{NIO}$ is necessary to make concluding statements about the cyclone-induced primary production and its key drivers. This is very important in the context of changes in climate in the form of global warming, global SST rise, increase in oceanic heat content, and changes in global wind patterns that directly affect cyclogenesis, cyclone tracks and associated biological production.

Apart from its significance in understanding the nutrient chemistry, it is important to understand the dynamics and biology of NIO during the cyclone events. This would help modelling of ocean state ${ }^{32}$, and ocean biogeochemistry, as most models fail to accurately simulate the observed $\mathrm{Chl}$-a concentrations and primary production. In addition, since NIO is a very complex region with two similar yet contrasting oceanic basins, information on the mechanisms triggering the biological production can enhance our understanding of the impact of climate change $\mathrm{e}^{33,34}$ on oceanic productivity and carbon cycling. Therefore, we make a comprehensive assessment on the link between tropical cyclones and phytoplankton bloom, and the physical mechanisms controlling the processes in NIO using satellite measurements for the period 1997-2019. The data are generally sparse during the cyclone passage due to dense clouds, strong winds and heavy rainfall, which also indicates the importance of this study as it considers a long-term single dataset for the entire study period, two different ocean basins, various category cyclones and all seasons for the analysis.

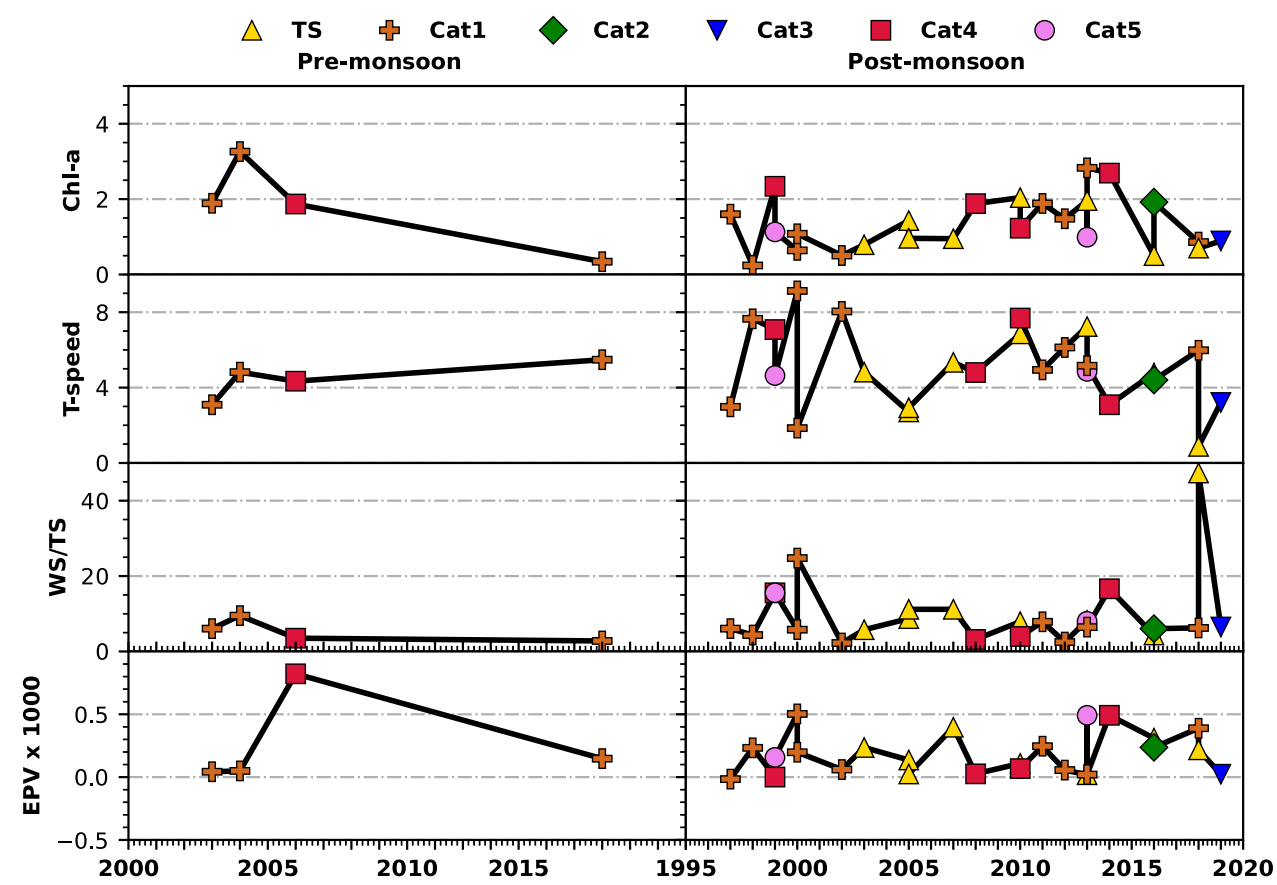

Fig. 2 The cyclone-induced Chl-a in BoB. The observed enhancement in $\mathrm{Chl}-\mathrm{a}\left(\mathrm{mg} / \mathrm{m}^{3}\right)$ following the cyclone passage (5-day average) in the post and pre-monsoon seasons in BoB. The translational speed of the closest track points where the bloom occurred in ( $\mathrm{m} / \mathrm{s})$, the ratio of wind speed to translational speed (WS/TS), and EPV (Ekman Pumping Velocity) as the cyclones reach their maximum intensity (m/s) are also shown in the lower panels. 
Table 1. The cyclone-induced Chl-a blooms in the pre-monsoon seasons since 1997 in BoB.

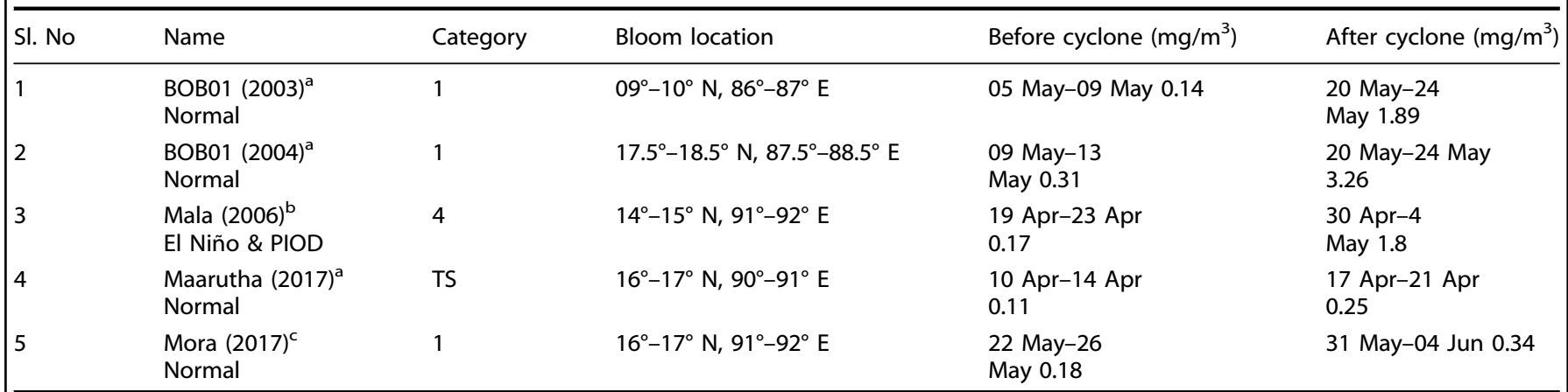

The second column also provides information on the phase of remote forcing, such as the years with El Niño, La Niña, positive IOD (Indian Ocean Dipole), negative IOD and normal years without any activity. The cyclone category from 1 to 5 and tropical storms (TS) are also indicated in the third column. The Chl-a bloom (in $\mathrm{mg} / \mathrm{m}^{3}$ ) estimated spatial grid ( $1^{\circ} \times 1^{\circ}$ latitude-longitude area, 4 th column), the Chl-a value before the cyclone period (5th column) and the Chl $-\mathrm{a}$ bloom after the passage (6th column) along with the dates are also noted.

The signs with the names of the cyclones in the second column indicate the direction of cyclone movement and their landfall such as-

asouth east.

${ }^{\mathrm{b}}$ North east.

'South west.

\section{RESULTS}

\section{Tropical cyclone-induced bloom in NIO}

We have analysed the tropical cyclones that occurred over the bay from 1997 to 2019 in accordance with the availability of satellite Chl-a measurements. Out of 51 storm events, 30 are identified as the phytoplankton bloom events (i.e. the Chl-a values greater than of $0.2 \mathrm{mg} / \mathrm{m}^{3}$ ) in BoB and 18 in AS across all seasons $\mathrm{s}^{35-37}$. In the case of $\mathrm{BoB}$, we have divided our analyses for pre-monsoon and post-monsoon, as the cyclone occurrences are rare in other seasons (e.g. winter and monsoon). Over AS, some cyclones also occur in the beginning of monsoon season. The spatio-temporal variability of cyclones is closely connected to the seasonal changes in the monsoon trough ${ }^{35,38}$. In pre-monsoon season, the trough passes over the northern $B o B$, but it passes through the central bay with an east-west orientation in the postmonsoon, and facilitates the formation of more number of TCs during the period ${ }^{39}$. The big seasonal change in wind shear and relative vorticity are the reasons for the lower number of cyclones in the pre-monsoon season. In general, the upwelling driven nutrient influx to the surface together with sunlight leads to the enhancement of Chl-a or phytoplankton bloom after the passage of cyclones in the open ocean ${ }^{40}$.

\section{The Bay of Bengal cyclones}

During pre-monsoon, the bay is least productive, but the western boundary current helps more production in the coastal regions ${ }^{41}$. The higher wind speed associated with TCs deepens (about $30 \mathrm{~m}$ ) Mixed Layer Depth (MLD), and rupture the pycnocline and pumps nutrients to the surface ${ }^{24}$. In general, TCs occurring during premonsoon move northwards and pass north-eastern coast of India or Bangladesh ${ }^{42}$ (Fig. 1). To estimate the cyclone-induced phytoplankton bloom, we performed spatial analyses for each cyclone during the period 1997-2019 and selected cases are shown in Supplementary Fig. 1 for BOB01 in 2003, BOB01 in 2004 and Mala in 2006. The maps of Chl-a concentrations superimposed with Sea Level Anomaly (SLA) for the same period are shown in Supplementary Fig. 1. The cyclone BOB01 was a category 1 storm with a maximum sustained wind (MSW) of $39 \mathrm{~m} / \mathrm{s}$, which occurred during 10-19 May 2003. The Chl-a remained well below $0.2 \mathrm{mg} / \mathrm{m}^{3}$ prior to occurrence of the cyclone, which enhanced to $0.5 \mathrm{mg} / \mathrm{m}^{3}$ with a small area of about $1 \mathrm{mg} / \mathrm{m}^{3}$ at $9^{\circ}-10^{\circ} \mathrm{N}, 86^{\circ}-87^{\circ} \mathrm{E}$, just after passage of the cyclone. This is consistent with its high Ekman
Pumping Velocity (EPV) and small Translational Speed (TS) in that period. In addition, the Chl-a enhancement was higher for the Category 1 cyclone BOB01 that occurred during 14-19 May 2004 and was about $0.5 \mathrm{mg} / \mathrm{m}^{3}$ after passage of the cyclone. The bloom sustained for the next 5 days as also shown in Supplementary Fig. 1. On the other hand, Mala was the strongest cyclone occurred during the pre-monsoon period (24-28 April 2006) in the last two decades over BoB with a MSW speed of $61 \mathrm{~m} / \mathrm{s}$. The Chl-a increased from 0.1 to $1.0 \mathrm{mg} / \mathrm{m}^{3}$ after the cyclone passage in five days, with a small area of Chl-a about $1.0 \mathrm{mg} / \mathrm{m}^{3}$ on the immediate left of its track. The Chl-a concentration remained close to $0.5 \mathrm{mg} /$ $\mathrm{m}^{3}$ in the next 5 days. Both EPV and TS were favourable for sustained upwelling and Chl-a bloom in the case of cyclone Mala. In all three cases, the closed contours of Sea surface Height Anomaly (SSHA) is negative, which indicate the presence of coldcore (cyclonic) eddies that triggered turbulent mixing and sustained $\mathrm{Chl}-\mathrm{a}$ bloom. We have not used any specific eddy detection method but used the composite of SSHA to identify the presence of eddies, as done by Girishkumar et al. ${ }^{43}$.

We applied the same method to identify the phytoplankton bloom that occurred for each cyclone event in BoB after 1996 and estimated the corresponding EPV and TS for diagnosing the physical mechanisms that made different scales of blooms. The results are presented in Table 1 and Fig. 2. The analyses show that the bloom was comparatively larger for the cyclone BOB01 in 2004, about $3.28 \mathrm{mg} / \mathrm{m}^{3}$. The increase in Chl-a is negatively correlated with TS and is in agreement with the intensity of cyclone with a statistically significant correlation value of -0.30 (at the $95 \%$ confidence interval as per the P-test ${ }^{44}$ ). The TS is lower and bloom is larger for BOB01 in 2003, as the faster moving storms tend to intensify rapidly when compared to slower moving storms (i.e. wind speed $14 \mathrm{~m} / \mathrm{s}$ ). In contrast, the slow-moving storms expend more time over the ocean and thereby, increases the magnitude of upwelling to enhance the $\mathrm{Chl}$-a over the region ${ }^{45}$. The estimated EPV is about $1.8 \times 10^{-4} \mathrm{~m} / \mathrm{s}$ for BOB01 in 2003 and is consistent with the observed $\mathrm{Chl}$-a concentrations, whereas the EPV is about $1 \times 10^{-4} \mathrm{~m} / \mathrm{s}$ and Chl-a concentration is about $1.87 \mathrm{mg} / \mathrm{m}^{3}$ for the cyclone Mala. It suggests that TS has a prominent role in cyclone-induced upwelling and associated phytoplankton bloom.

Post-monsoon is the active storm season over $\mathrm{BoB}$, and about 25 cyclones with significant enhancement in Chl-a concentration are identified during the 1997-2019 period. As the haline 

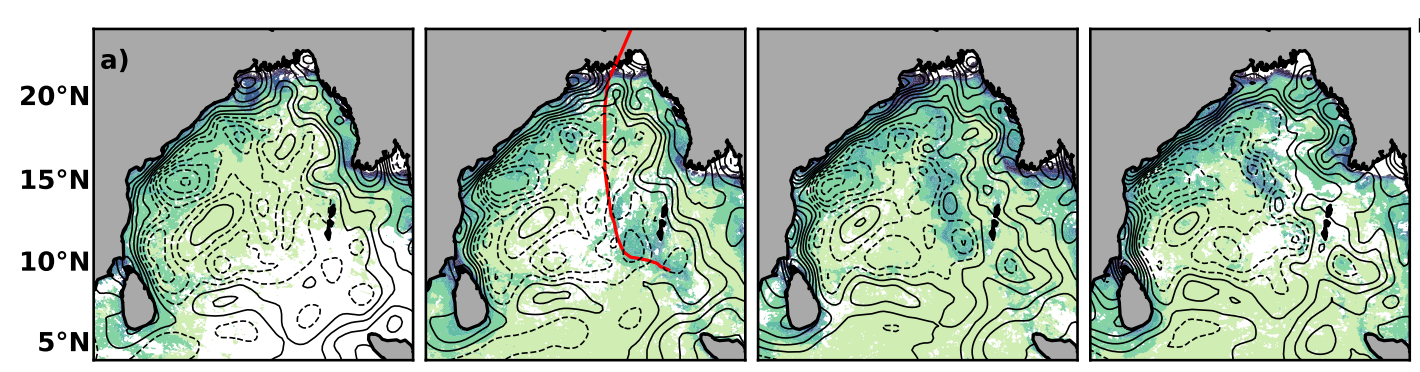

$\mathbf{m g} / \mathbf{m}^{3}$
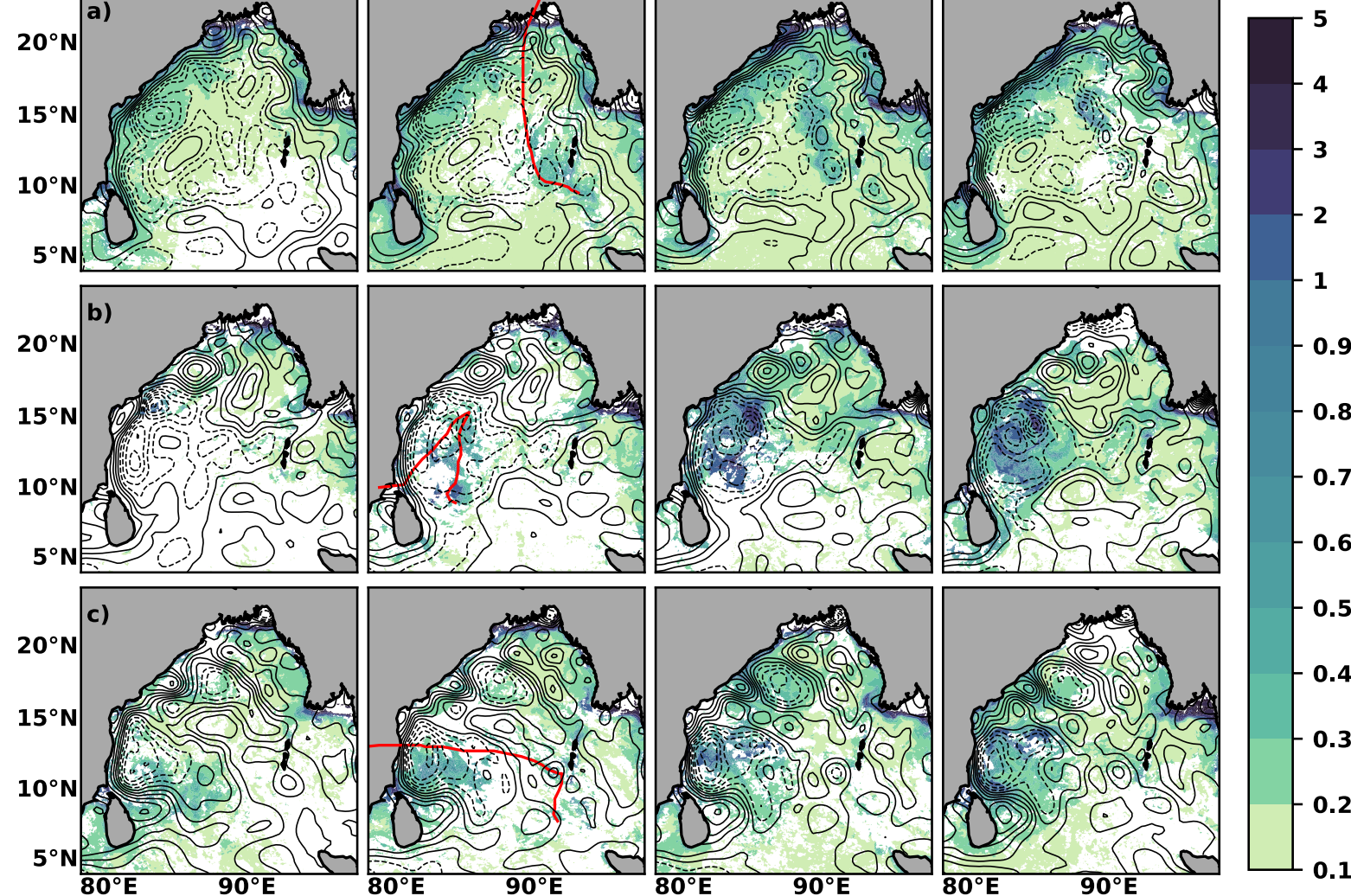

Fig. 3 The spatial extension of Chl-a bloom for selected post-monsoon cyclones in BoB. The Chl-a averaged, overlaid with SSHA contours (solid-positive and dashed-negative), for 5 days before cyclone, during the entire cyclone period, five days just after the passage of cyclone and next 5 days for a Sidr (2007), b Madi (2013), and c Vardah (2016). The tracks of the respective cyclones are also shown.

stratification is stronger in $B O B$ due to the monsoon rain and river water influx, the presence of BL increases SST, which fuel the storms over the bay ${ }^{46}$. Presence of $\mathrm{BL}$ weakens the impact of cooling in the mixed layer driven by cyclones and favours the intensification of post-monsoon cyclones ${ }^{2}$. We have also analysed the variability in BL, MLD, isothermal layer depth (ILD) and Chl-a for selected storms passed over the Argo Floats (see next section). The cyclones either form or develop further over the southeast BoB, but some move west northwest and cross the peninsular coast. Some cyclones recurve towards the west central bay and pass the central and northeast coast of India, but some hit Bangladesh and upper Burma coast ${ }^{47}$, as illustrated in Fig. 1.

Figure 3 presents a closer look at the bloom and its spatial distribution for selected cyclones during the post-monsoon season; e.g. the cyclones Sidr, Madi and Vardah overlaid with SSHA contours. Sidr, a category 4 cyclone occurred during 11-16 November 2007 with a MSW of about $44 \mathrm{~m} / \mathrm{s}$. The Chl-a is about $0.5 \mathrm{mg} / \mathrm{m}^{3}$ during the cyclone period at the right side of the track, but the bloom has spread to a wider area with values close to $0.5 \mathrm{mg} / \mathrm{m}^{3}$ just after the passage of cyclone. The analyses of SSHA further provide evidence for the eddy-mediated phytoplankton bloom. The phytoplankton bloom also sustained for another 5 days. This is also in agreement with that reported in other analyses, although bloom values were estimated for 19 November in the other studies ${ }^{48,49}$. The cyclone Madi, occurred during 6-13 December 2013, showed an enhancement of about $0.5 \mathrm{mg} / \mathrm{m}^{3}$ during the cyclone period with a region of $1 \mathrm{mg} / \mathrm{m}^{3}$ in the left side of the track. Some regions with $2-3 \mathrm{mg} / \mathrm{m}^{3}$ are also observed at the right and left sides of cyclone track, and the bloom sustained for the next 5 days with values of about $1 \mathrm{mg} / \mathrm{m}^{3}$ in the adjacent areas. The closed contours of negative SSHA suggest the presence of cyclonic eddies there. The phytoplankton bloom during this particular period is also contributed by the cyclone Lehar that occurred a week before, in 23-28 November; demonstrating the impact of occurrences of consecutive storms over the same oceanic region. Nevertheless, the cyclone Vardah showed an enhancement of about $1.92 \mathrm{mg} / \mathrm{m}^{3}$, which is higher than that of Sidr due to the higher EPV of the former. As for Lehar and Madi, there was another cyclone Nada that appeared during the period 29 November-2 December 2016, just before the appearance of Vardah, and that storm might have also contributed to the Chl-a bloom during the period of Vardah.

Figure 4 shows the time evolution of physical and biological observations during the period of TCs Phailin, Hudhud and Vardah. The biogeochemical Argo float WMO ID 2902086 was closer to the track of TC Phailin, and the float WMO ID 2902114 was near the tracks of Hudhud and Vardah. Supplementary Table 1 shows the name of cyclones, Argo IDs, and distance between the float and nearest track point of respective cyclones. Figure 4 (right) represents the subsurface temperature up to $200 \mathrm{~m}$ with MLD, ILD, BLT and D23 (23 isotherm) for selected cyclones occurred over BoB. Figure 4 (left) represents the subsurface $\mathrm{Chl}$-a concentration up to $200 \mathrm{~m}$ driven by the same cyclones. Prior to the passage of cyclones, the profiles represent typical hydrographic state of the oceans with warm waters near the surface and cold waters in the subsurface. The MLD was shallower about $20 \mathrm{~m}$ and the ocean was warm from September to December in 2013 during the passage of cyclone Phailin. The other cyclones occurred in 2013 were Helen, Lehar and Madi. Similar situation was observed in September-December of 2014 for Hudhud, but a colder and deeper MLD is observed in September-December of 2016 for Vardah. These are consistent with the climatological oceanic characteristics observed in BoB during the post-monsoon seasons. The time-depth cross-section of $\mathrm{Chl}-\mathrm{a}$ reveals that the $\mathrm{Chl}-\mathrm{a}$ 

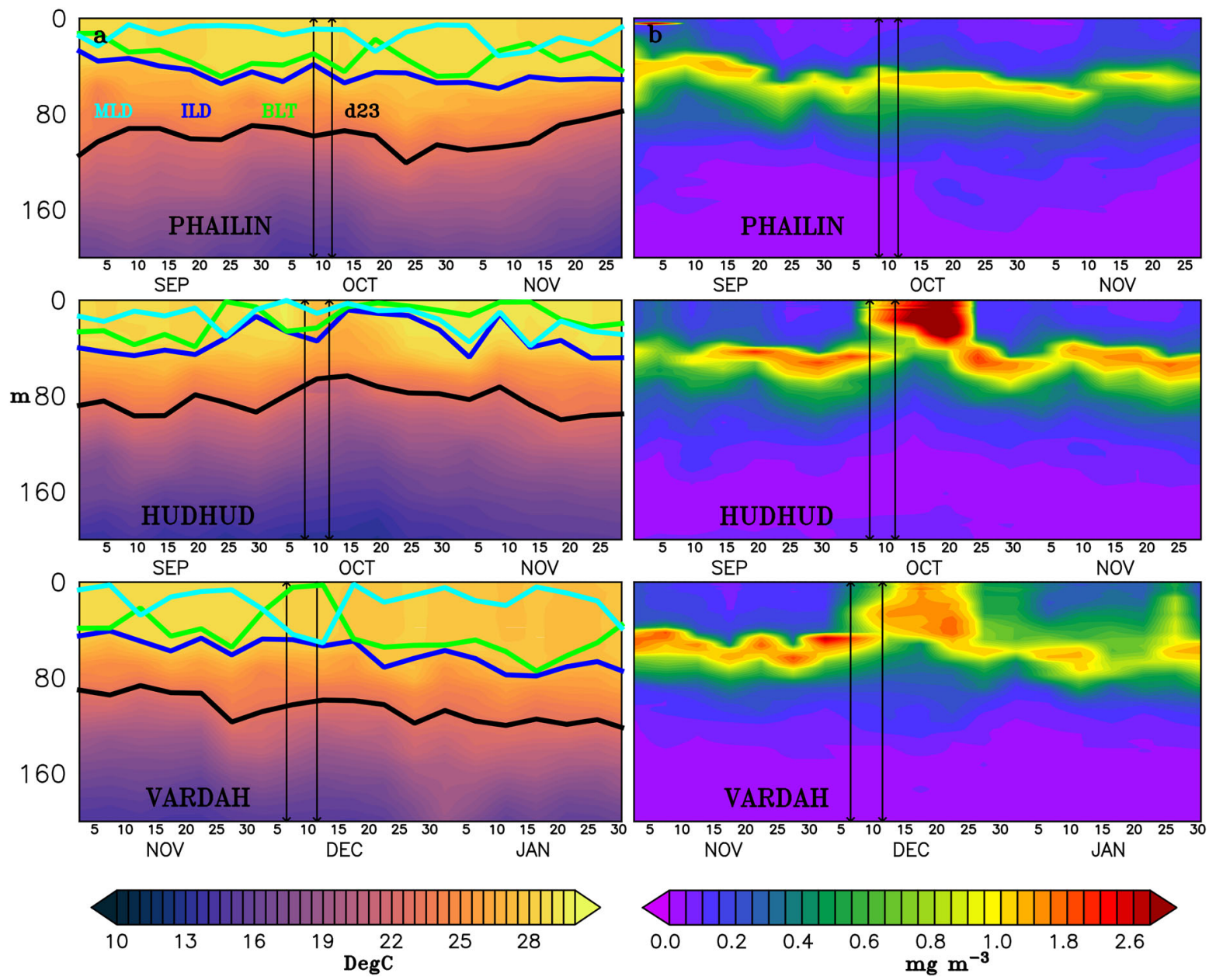

Fig. 4 Bio-Argo measurements. Temporal evolution (right panel) of depth-time section up to $200 \mathrm{~m}$ of temperature of some selected cyclones in the BoB. The MLD (cyan), ILD (blue), BLT (green), and D23 (black) are also indicated in the figure. The vertical black lines indicate the cyclone period. The subsurface Chl-a concentration (left panel) up to $200 \mathrm{~m}$ for some selected cyclones in BoB. The vertical black lines indicate the cyclone period.

concentration remains small in the surface, but about $0.8-1.0 \mathrm{mg} /$ $\mathrm{m}^{3}$ at $40-60 \mathrm{~m}$ for the cyclone Phailin. The Chl-a concentration is about $3 \mathrm{mg} / \mathrm{m}^{3}$ for the cyclone Hudhud and about $1.5 \mathrm{mg} / \mathrm{m}^{3}$ for Vardah.

To identify the differential oceanic response of the cyclones at the Argo float locations, we further examined the presence of eddies that play a major role in regulating the physical and biogeochemical processes. The analysis of 7-day SSHA composite before and during the cyclone period at the location of Argo float shows the presence of cold-core (negative SSHA) eddies before the passage of cyclone Phailin, Madi and Hudhud, whereas a warm-core (positive SSHA) eddy prior to the passage of Vardah (Fig. 5). The lower TS and a cold-core eddy during the cyclone Hudhud, and higher TS and a warm-core eddy during the cyclone Vardah produce contrasting oceanic response ${ }^{43}$. The temperature measurements during the periods of Hudhud and Vardah exhibit comparable response to cold and warm-core eddies, respectively. Another feature of cold-core eddies is trapping the near inertial oscillations in the mixed layer ${ }^{50}$, which accelerates the entrainment at the bottom of mixed layer and vertical shear as observed during the period of Hudhud. Conversely, the proximity of warmcore eddies triggers rapid vertical dispersion of near inertial energy, which suppresses the mixing and shear as for Vardah ${ }^{50}$.

Vardah was a category 1 cyclone that occurred during 6-13 December 2016. The Chl-a amount before the passage of cyclone was about $0.23 \mathrm{mg} / \mathrm{m}^{3}$, but it escalated to $1.92 \mathrm{mg} / \mathrm{m}^{3}$ in 5 days after the passage of cyclone. The bloom continued to exist for the next 5 days as shown in Fig. 3. Unlike the pre-monsoon cases, for which the Chl-a is restored back to open ocean values in 10 days after the passage of cyclones, the bloom continued to persist even longer periods for the post-monsoon cases. The changes in Chl-a concentrations before and after the passage of cyclones in all three cases are greater than $0.2 \mathrm{mg} / \mathrm{m}^{3}$ and are higher for the lower category tropical storms. These analyses are consistent with the frequent occurrence of cyclones over the south east BoB during this season, as shown in Supplementary Table 2. It is also compelling to note that higher intensity cyclones occur over the north as compared to south $\mathrm{BoB}$, which may be due to the presence of $B L$ in the northern $B o B$ as $B L$ does not exist or insignificantly shallow in the south $B o B$ in any season. The barrier layer in turn favours intensification of tropical cyclones whereas the absence of $\mathrm{BL}$ favours the storm-induced upwelling that eventually makes the Chl-a blooms ${ }^{45}$. Note that the stratification is very strong in northern $\mathrm{BoB}$ due to the river water input there ${ }^{51}$.

Supplementary Table 2 and Fig. 2 also show the results of Chl-bloom events in the post-monsoon seasons in 1997-2019. For instance, the Chl-a increased from 0.53 to $1.13 \mathrm{mg} / \mathrm{m}^{3}$ in the northern and southwestern BoB after the super cyclone of 1999 (25 October-3 November), as also shown by Madhu et al. ${ }^{52}$. Similar enhancements in Chl-a are estimated for BOB08 (1997), BOB05 (2000) and Madi (2013), about $0.6-3 \mathrm{mg} / \mathrm{m}^{3}$, depending on the cyclones. Although the cyclones BOB06 (1999), Sidr (2007), Giri 


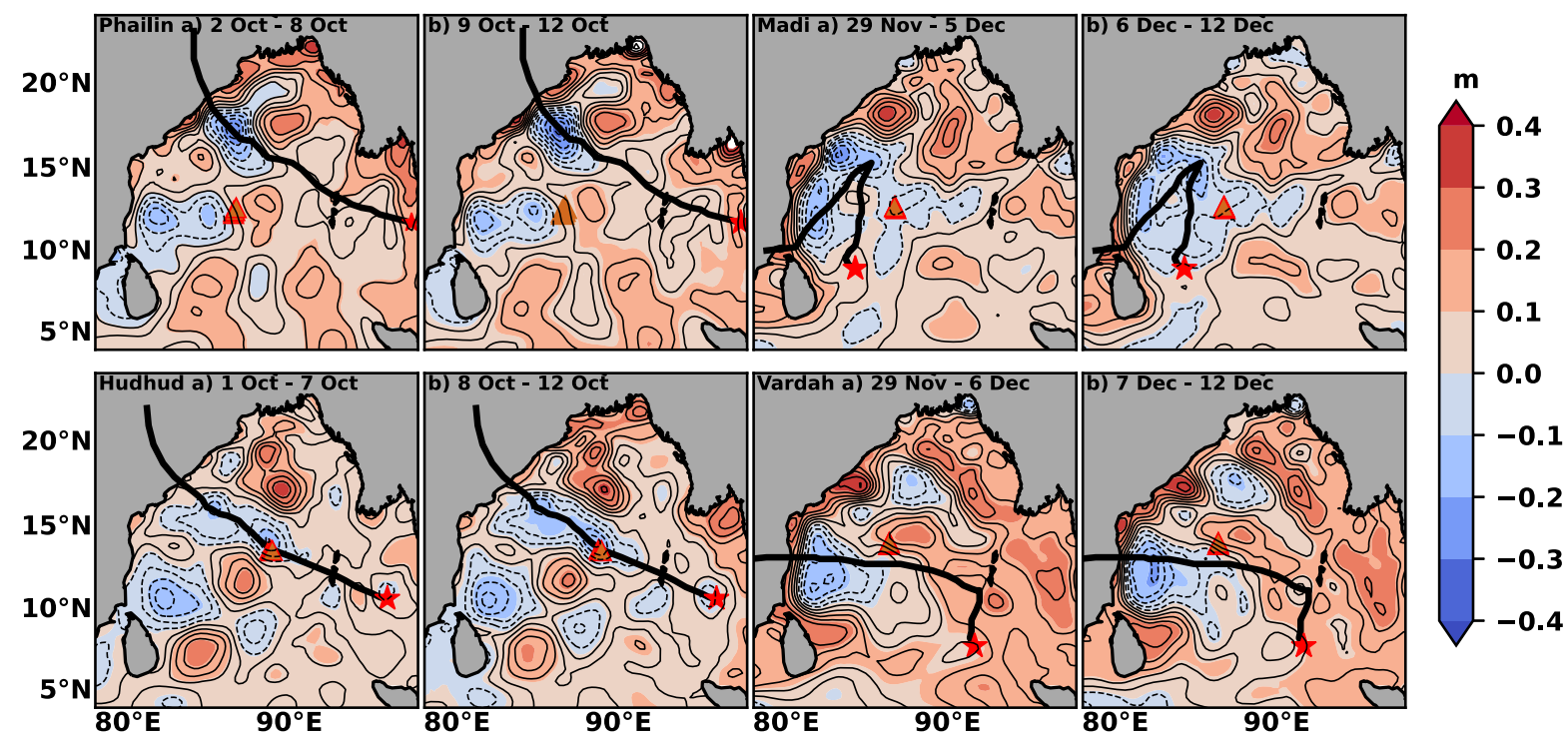

Fig. 5 Eddies and primary productivity. The 7-day composite of sea level anomaly $(\mathrm{m})$ before and during the cyclones in BoB. The black solid lines represent the cyclone tracks, the stars represent the genesis location of the cyclone and the box represents the Argo float location.

(2010) and Phailin (2013) were category 4 or 5 cyclones, the high TS and lower EPV did not magnify the Chl-a concentrations to the level of bloom initiated by other cyclones. The enhancement of Chl-a estimated in our study during the cyclone Phailin is in agreement with the reported value of $0.9 \mathrm{mg} / \mathrm{m}^{3}$ for the period 16-24 October 2013 by Vidya et al. ${ }^{21}$. They also computed the bloom associated with Thane, about $0.7 \mathrm{mg} / \mathrm{m}^{3}$ in the postcyclone period (1-8 January 2012) at $10^{\circ}-13^{\circ} \mathrm{N}$ and $82^{\circ}-86^{\circ} \mathrm{E}$. Nevertheless, we have estimated about $1.8 \mathrm{mg} / \mathrm{m} 3$ for the postcyclone period for Thane. The cyclone Hudhud produced a Chl-a bloom of up to $2.8 \mathrm{mg} / \mathrm{m}^{3}$ in 8-15 October 2014 along the track, as analysed by Chacko ${ }^{27}$ using the MODIS data, which is very close to our estimate of $2.8 \mathrm{mg} / \mathrm{m}^{3}$. We find similar enhancements in Chl-a that reported by Rao et al. ${ }^{26}$ for BOB05 in 16-23 November 2000, about $1.2 \mathrm{mg} / \mathrm{m}^{3}$ as deduced from the MODIS data. The other cyclones show moderate bloom values, below $1 \mathrm{mg} / \mathrm{m}^{3}$ as listed in Supplementary Table 2. Nevertheless, the low intensity cyclones such as BOB08 (1997) and Thane (2011) exhibit notable increment in Chl-a following the passage of cyclone, about $1.25-1.8 \mathrm{mg} / \mathrm{m}^{3}$, which is in agreement with their comparatively lower TS and higher EPV during the cyclone period. It also attests the impact and significance of TS in deciding the amplitude of phytoplankton bloom; suggesting sustained low intensity winds trigger strong upwelling to cause intense bloom events.

\section{The Arabian Sea cyclones}

In Arabian Sea, about 18 out of 33 cyclones are identified as phytoplankton bloom events (55\%) during the study period 1997-2019, in which one occurred in pre-monsoon, three in monsoon and nine in post-monsoon seasons. Since the frequency of occurrences is very small, we have not separated the analyses into seasons or regions of landfall, but a selected case is presented in Supplementary Fig 2. For a better understanding of the behaviour of cyclones, we have selected three cyclones, ARB01 (2001), Mukda (2006) and Megh (2015), one in each season for this discussion. Supplementary Fig 3 illustrates the spatial distribution of Chl-a superimposed with SSHA for the selected cyclones. The ARB01 (2001) was a category 3 cyclone that occurred during 21-28 May 2001 with a MSW of about $60 \mathrm{~m} / \mathrm{s}$. The surface Chl-a concentration before the cyclone appearance was below $0.2 \mathrm{mg} /$ $\mathrm{m}^{3}$ due to the profound heating in May ${ }^{53,54}$. It was one of the strongest cyclones appeared over AS, but measurements were sparse during the cyclone period, and thus, only a small area of about $1 \mathrm{mg} / \mathrm{m}^{3}$ is observed at $16^{\circ}-17^{\circ} \mathrm{N}, 69^{\circ}-72^{\circ} \mathrm{E}$ after passage of the cyclone. Analysis of IRS-P4 measurements by Subramanyam et al. ${ }^{29}$ found a very large bloom of about $5-8 \mathrm{mg} / \mathrm{m}^{3}$ at $17^{\circ}$ $\mathrm{N}$, from $67^{\circ} \mathrm{E}$ to $71^{\circ} \mathrm{E}$. However, our analyses show the bloom of about $2.07 \mathrm{mg} / \mathrm{m}^{3}$ in the region $67^{\circ}-68^{\circ} \mathrm{E}, 16^{\circ}-17^{\circ} \mathrm{N}$. The difference in bloom values could be due to the difference in datasets, region and period of analyses. As found in the case of $\mathrm{BoB}$, there are closed contours of negative SSHA, which strengthens the observed cyclone-induced and eddy-mediated phytoplankton bloom.

Mukda was a tropical storm that occurred during 21-24 September 2006 with a MSW of $28 \mathrm{~m} / \mathrm{s}$. The Chl-a along the right side of the track was above $0.5 \mathrm{mg} / \mathrm{m}^{3}$ even before the cyclone period. The cyclone Megh was considered as the worst to hit Yemen and it occurred just after the passage of another cyclone Chapala over the same region. Megh was a category 3 cyclone with a MSW of $57 \mathrm{~m} / \mathrm{s}$. The Chl-a was about $0.7 \mathrm{mg} / \mathrm{m}^{3}$ in the postcyclone stage, but a small region of about $1.0 \mathrm{mg} / \mathrm{m}^{3}$ was also observed at the right end of the track. Table 2 and Fig. 6 show the analysis of phytoplankton bloom occurrences in AS during the study period (1997-2019). It shows higher Chl-a concentrations in connection with the cyclones ARB01 and ARB02 in 2001, Mukda in 2006 and Megh in 2015, and are consistent with their lower TS. The situation in 2015 was also similar, in which the Category 4 cyclone Chapala showed higher bloom than that of the category 3 cyclone Megh. Similarly, the Category 4 cyclone Kyaar triggered higher bloom than that of the Category 3 cyclone Maha in 2019.

Supplementary Fig. 3 shows the time evolution of biological and physical observations from the Argo float (WMO ID 2902120) in the period of TCs Nilofar, Chapala and Megh. The distance between float location and nearest track point is provided in Supplementary Table 1 . The temperature profiles show warm waters near the surface and cold waters in the subsurface before the cyclone passage, as for a typical oceanic state (Supplementary Fig. 4). The MLD is shallower about $20 \mathrm{~m}$ and the ocean is warm throughout September-December 2014 and October-December 2015 during the passage of cyclones Nilofar, Megh and Chapala. The time-depth cross-section of chlorophyll shows about $0.8-1 \mathrm{mg} / \mathrm{m}^{3}$ at $40-60 \mathrm{~m}$. However, the Chl-a values remain about $1 \mathrm{mg} / \mathrm{m}^{3}$ for cyclones Megh and Chapala close to the surface; supporting the satellite measurements. The analysis of 7-day SSHA composite shows a cold-core eddy before the passage of cyclone Nilofar whereas warm-core eddies before the passage of Chapala 


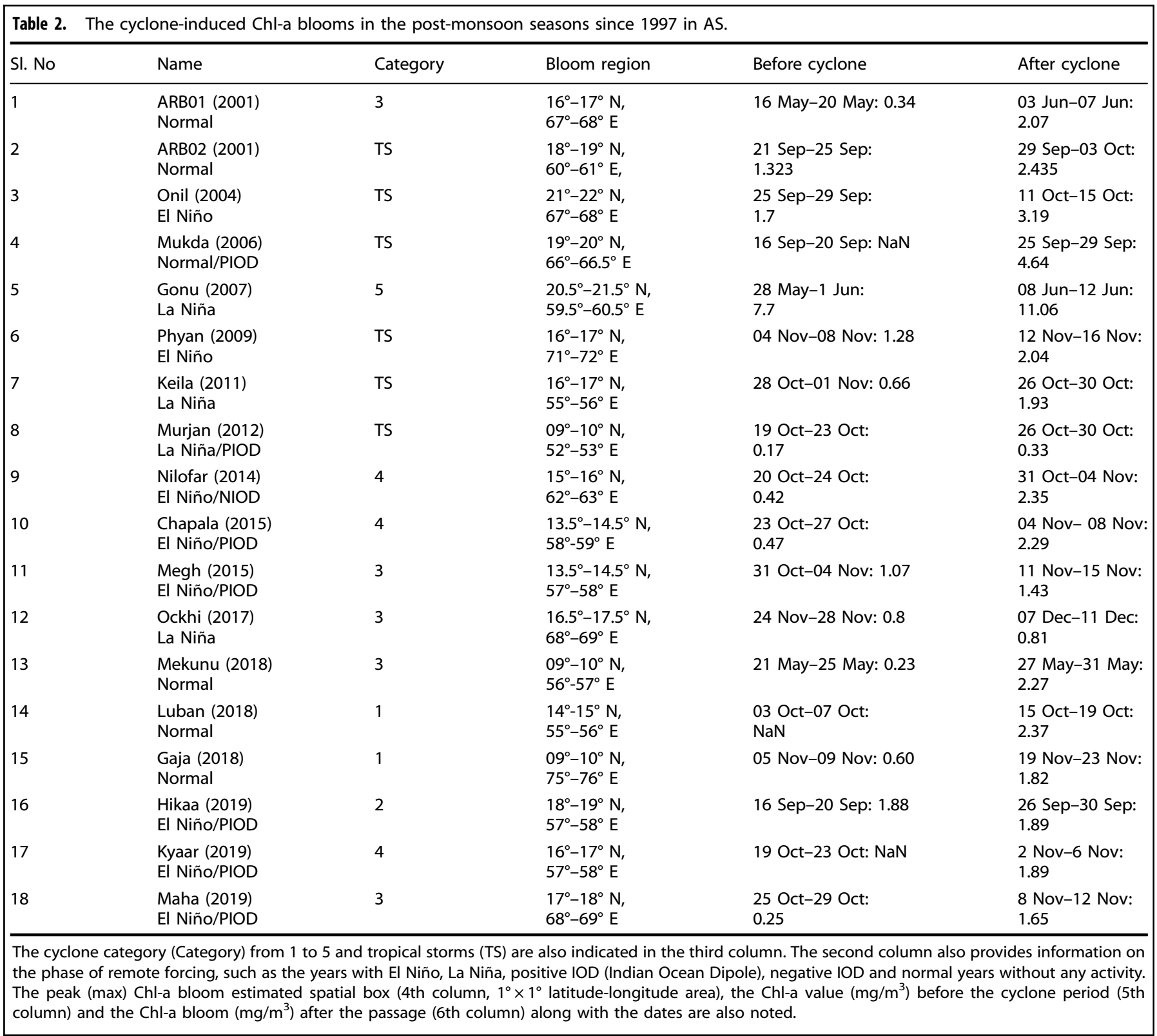

and Megh at the buoy location (Supplementary Fig. 5). The warmcore eddies before the passage of Chapala and Megh could also be the reason for their rapid intensification.

\section{Tropical storms and category 1 cyclones}

Although a number of cyclones occurred over NIO during the 1997-2019 period, the phytoplankton bloom happened mostly for the storms and lower category cyclones. For instance, there were five cyclones that appeared over BoB in the pre-monsoon seasons that triggered phytoplankton bloom, four (80\%) of them were either tropical storms or category 1 cyclones (Table 1). Similarly, out of 25 cyclones that made Chl-a blooms in BoB during the postmonsoon seasons, 20 of them were (80\%) either tropical storms or category 1 cyclones. An analogues occurrence of cyclone-induced phytoplankton bloom is observed for the lower category cyclones in AS, where eight cyclones out of 18 (44.4\%) were either tropical storms or category 1 cyclones. These analyses suggest that the slow-moving storms stay more time over the oceans and impart high momentum to upwell the subsurface nutrient-rich water, leading to the phytoplankton blooms in the open oceans with a time lag of 4-12 days, as illustrated in Fig. 7 (blue coloured bar chart). The bloom is as higher as about $20-500 \%$ with respect to the pre-cyclone Chl-a levels, and is even up to $1385 \%$ as for the case of BoB01 in 2003 and 3758\% for the cyclone Gonu in AS (Supplementary Fig. 6); demonstrating the impact and scale of cyclone-induced primary productivity in the open oceans. This slow-moving cyclone-induced primary productivity is very important in the context of climate change, as there is a global slowdown in the translational speed of tropical cyclones.

To test robustness of the estimates of cyclone-induced change in Chl-a (i.e. Fig. 7), we also considered two other background Chla values (i.e. 0.2 and $0.5 \mathrm{mg} / \mathrm{m}^{3}$ ), which were also taken as the background Chl-a of the ocean basins and the Chl-a threshold for bloom detection. Since the value extracted from the $1^{\circ} \times 1^{\circ}$ latitude-longitude region at the track (i.e. blue diagrams) is different from the basin average and bloom threshold values, there are significant differences in the amplitude of blooms, as displayed in Fig. 7. It shows that the pre-cyclone $\mathrm{Chl}$-a values are between 0.5 and $0.2 \mathrm{mg} / \mathrm{m}^{3}$. Therefore, the change in Chl-a is 


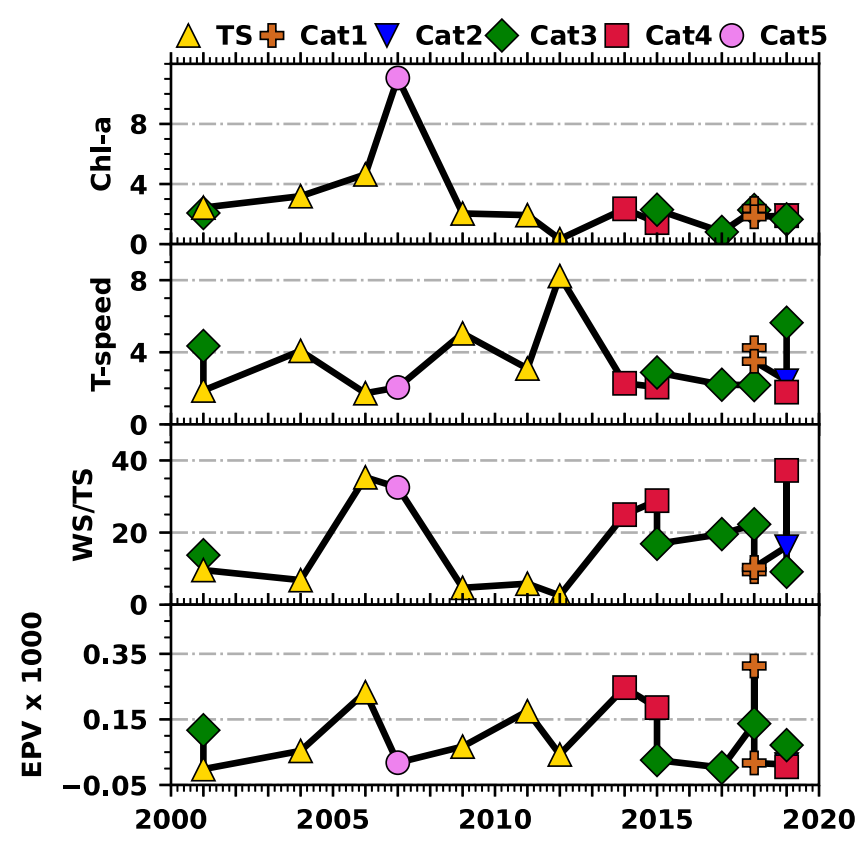

Fig. 6 The Chl-a blooms associated with cyclones in Arabian Sea. The observed enhancement in Chl-a $\left(\mathrm{mg} / \mathrm{m}^{3}\right)$ following the cyclone passage (5-day average) over AS. The translational speed of the closest track points where the bloom occurred in $(\mathrm{m} / \mathrm{s})$, the ratio of wind speed to translational speed (WS/TS) and EPV when cyclone reached its maximum intensity $(\mathrm{m} / \mathrm{s})$ are also shown.

higher with the estimates based on $0.2 \mathrm{mg} / \mathrm{m}^{3}$ (magenta histogram) and about 10 cyclones show a change in Chl-a of about $400 \%$. The highest bloom of about $800-850 \%$ is found for Madi (2013), Hudhud (2014) and BOB05 (1999). On the other hand, the change in Chl-a with respect to $0.5 \mathrm{mg} / \mathrm{m}^{3}$ (dark blue histogram) is lower than that with the pre-cyclone estimates, and the change is mostly within $250 \%$, although few cyclones show around $400 \%$. The highest bloom is observed for the cyclone Madi (2013), about 300\%. In AS, the Chl-a bloom is mostly between 300 and $1000 \%$, except for Gonu in 2007. The change in $\mathrm{Chl}-\mathrm{a}$ is about $6000 \%$ with respect to the basin average of $0.2 \mathrm{mg} /$ $\mathrm{m}^{3}$, and about $3500 \%$ based on the bloom threshold for the cyclone Gonu. The assessment confirm that the cyclone-induced bloom (change in percent) in AS is about five times higher than that of BoB.

\section{The impact of ENSO and IOD on Chl-a blooms}

Several studies have examined the relationship between El Niño and Southern Oscillation (ENSO) and cyclone activity across different oceanic basins ${ }^{12,55,56}$. The influence of ENSO on tropical cyclone activity in BoB during the period 1997-2010 is also investigated by Girishkumar et al. ${ }^{19}$. We have chosen the dates after the cyclone passage, and considered the Niño and IOD indices to classify the cyclones occurred in the El Niño, La Niña, normal, positive IOD (PIOD) and negative IOD (NIOD) years, as listed in Table 1, Table 2 and Supplementary Table 2. In addition, we have prepared the composites of Chl-a and SSHA for 10 days before and after the passage of each cyclone to assess the interannual variability in Chl-a and SSHA with respect to the El Niño, La Niña, normal, PIOD and NIOD years (Fig. 8, for BoB). Out of the 25 cyclones, three of them occurred in El Niño, fourteen in La Niña, nine in normal, four in PIOD and five in NIOD years. The cyclones those occurred in PIOD or NIOD years also happened to be in the El Niño/La Niña years and therefore included in both analyses, and are shown in the figure. The number of cyclones are more in the La Niña years, which were mostly followed by the normal, PIOD and NIOD years. The magnitude of phytoplankton bloom is higher in the PIOD years than that in the NIOD years. In the El Niño years, the magnitude of bloom is comparatively smaller and the bloom in normal years is around $0.5 \mathrm{mg} / \mathrm{m}^{3}$.

Supplementary Fig. 9 shows the composite of SSHA and Chl-a with respect to El Niño, La Niña, normal, PIOD and NIOD years in AS. Here, more number of cyclones occurred in the El Niño years as compared to that in the La Niña and normal years. In contrast, there are more number of cyclones in the PIOD years than the NIOD years in AS, but the amplitude of bloom is higher for the NIOD years. These are also the reasons for the differences in phytoplankton bloom in AS and BoB, as the impact of ENSO and IOD events is different in both basins. The response of cyclones in IOD years are similar to those in the La Niña years. Although the spatial extent of bloom is larger in the El Niño years owing to the higher number of cyclone occurrences, the magnitude of bloom is higher for the cyclones occurred in La Niña and NIOD years. The normal years exhibit bloom similar to that of the El Niño years. In BoB, the analysis of SSHA composite for the El Niño, La Niña, IOD and normal years is dominated by negative SSHA (suggesting the presence of cold-core eddies), but the normal years are more influenced by warm-core eddies (e.g. Fig. 8). In AS, on the other hand, the normal, La Niña and IOD years are dominated by coldcore eddies, whereas the El Niño years are overwhelmed by warmcore eddies (e.g. Supplementary Fig. 9). The influence of IOD is higher than that of ENSO, which is one of the reasons for the interannual variability of phytoplankton blooms. The characteristics of phytoplankton blooms in $\mathrm{AS}$ and $\mathrm{BoB}$ are in contrast with the differences in SST in IOD years in both basins, and this feature is also found with the cyclone-induced blooms. There are noticeable difference in Chl-a concentrations among the normal and El Niño, La Niña, PIOD or NIOD years, and are exhibited in Supplementary Figs. 7 and 8.

\section{DISCUSSION}

Our study finds that the frequency of cyclones and the cycloneinduced phytoplankton blooms are high in the post-monsoon in $\mathrm{BoB}$ and AS. The duration of bloom events is longer for the cyclones in the post-monsoon season, about 10-14 days. Furthermore, the spatial extent of bloom is comparatively smaller for the pre-monsoon cyclones and the bloom occurs about 4-12 days after the passage of cyclones, depending on seasons and TS of the cyclones. The largest bloom of $3.28 \mathrm{mg} / \mathrm{m}^{3}$ is found with BOB01 in 2003 for the pre-monsoon cyclones and about $2.8 \mathrm{mg} / \mathrm{m}^{3}$ with Madi in 2013 for the post-monsoon cyclones in BoB. The highest bloom was made by cyclone Gonu in 2007 in AS, about $11 \mathrm{mg} / \mathrm{m}^{3}$. The strong winds associated with tropical cyclones initiate intense upwelling, which results into the enhancement of surface $\mathrm{Chl}-\mathrm{a}$ after the passage of cyclones. Additionally, the lower TS helps the cyclones to spend more time over the ocean that leads to strong and sustained upwelling to trigger the blooms. The presence of cold-core eddies near the tracks help the phytoplankton blooms. The cyclones occurred during La Niña drive higher blooms as compared to that in the normal and El Niño years. The cyclones in the positive IOD years produce more blooms in $\mathrm{BoB}$, but negative IOD years in AS. Note that the above conclusions are made with respect to the available measurements for each period (e.g. there are only four cyclone events in the El Niño periods over BoB for the period 1997-2019), and therefore, care must be exercised when used for interpreting the results and modelling the ocean biogeochemistry in different cyclone periods. Henceforth, our study provides a new outlook on the life cycle, seasonal change and magnitude of cyclone-induced phytoplankton blooms and primary productivity in NIO. These results would also give a good test for ocean models coupled with biogeochemistry. 


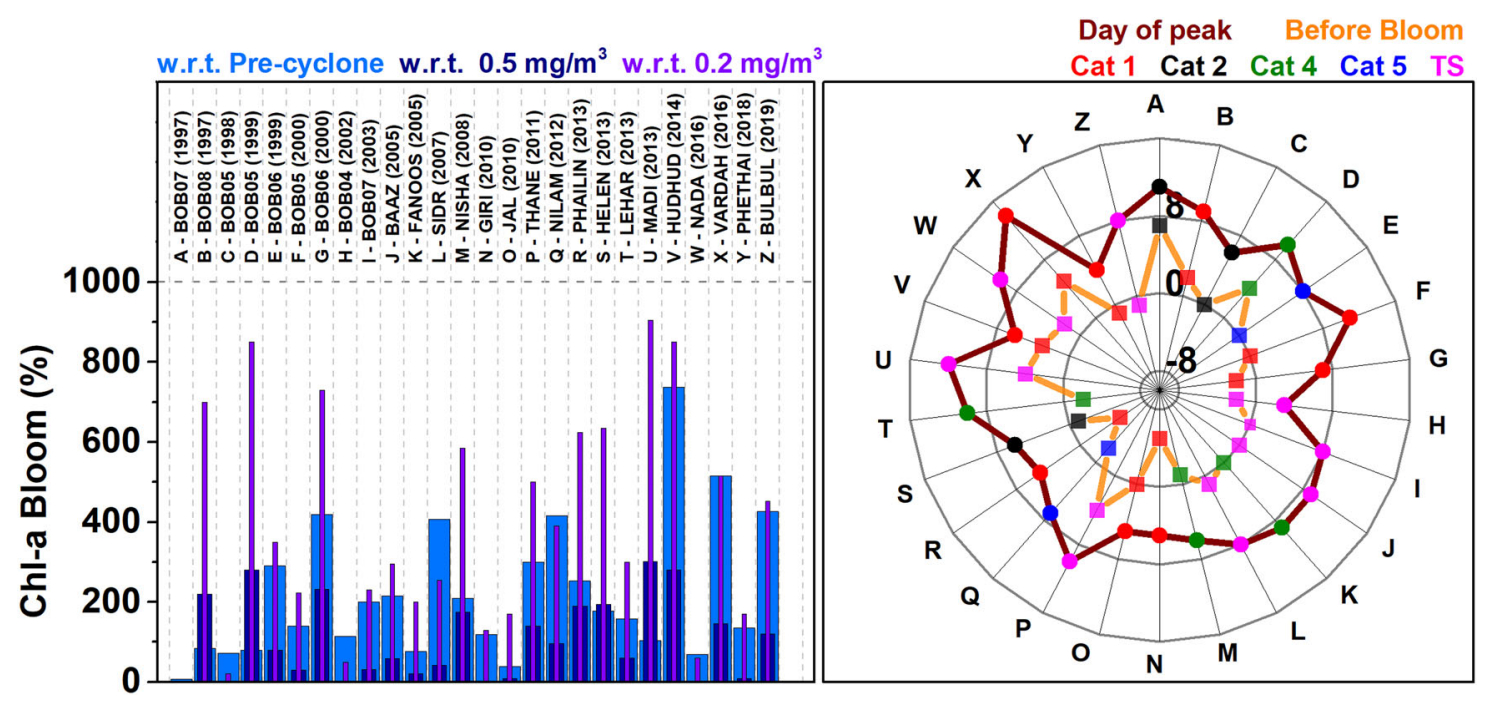

Fig. 7 The change in cyclone-induced bloom and time lag. Left: with respect to pre-cyclone Chl-a values (blue), $0.5 \mathrm{mg} / \mathrm{m}^{3}(\mathrm{dark}$ blue) and $0.2 \mathrm{mg} / \mathrm{m}^{3}$ (magenta) for the post-monsoon cyclones in Bay of Bengal (BoB). Right: The time lag in days in cyclone-induced Chl-a bloom with respect to the pre-cyclone $\mathrm{Chl}-\mathrm{a}$ (blue histograms, left) for the post-monsoon cyclones of BoB.

\section{METHODS}

\section{Data}

To understand the phytoplankton bloom associated with cyclone events, we used the satellite derived Ocean Colour Climate Change Initiative (OC-CCl) version 4.2 data. The OC-CCl data consist of bias corrected and merged (MEdium Resolution Imaging Spectrometer-MERIS: 2002-2012, MODIS on Aqua: 2002-to date and SeaWiFs: 1997-2010) satellite measurements on a $4 \times 4 \mathrm{~km}$ resolution for the period 1997-2019. Therefore, these data are suitable for long-term studies on the phytoplankton blooms and the data have an uncertainty of about $\pm 0.15 \mathrm{mg} / \mathrm{m}^{3}$, as mentioned in the user guide. The cyclone track, category, and duration information were taken from Joint Typhoon Warning Centre (JTWC) best track for the above-mentioned period. The data consist of position and intensity information at $6 \mathrm{~h}$ interval for the duration of each individual cyclone. As the JTWC track data were not available for 2019, we have used the Regional Specialized Meteorological Centre for Tropical Cyclones over North Indian Ocean, India Meteorological Department (IMD) six hourly track information. We use the Saffir-Simpson scale that distinguishes storms in different categories in accordance with the intensity or speed of associated winds. For the calculation of EPV we have used the European Centre For Medium Range Weather Forecast (ECMWF) Reanalyses (ER5) data $10 \mathrm{~m}$ winds of $25 \times 25 \mathrm{~km}$ resolution ${ }^{57}$. To analyse the role of oceanic eddies in cyclone-induced Chl-a blooms, we have examined the presence of eddies during the passage of cyclones by using the merged SLA data of a resolution of $25 \mathrm{~km}$ that are made from different space-borne altimeter measurements by the Copernicus Marine Environment Monitoring Services (CMEMS).

Apart from these, we use SSHA to check the presence of eddies, for which a 10-day composite of SSHA before and during the passage of cyclone is considered. In general, the cyclonic or cold-core eddies raise the thermocline and nutricline. Therefore, the accompanied mixing by turbulence can initiate entrainment of nutrient-rich cold subsurface water to the surface easily as compared to the case of no eddies or warm-core (anticyclone) eddies ${ }^{58-62}$. This would assist the cyclone-induced Chl-a blooms when the cyclone encounters cold-core eddies during their passage over the oceanic regions. Argo float (WMO ID 2902086, 2902114 and 2902120) measurements are also used to understand the bio-optical and hydrographic properties of oceanic regions during cyclone events. These floats measure physical and biological parameters in 5-day intervals between 5 and $2000 \mathrm{~m}$ at different depths. We have analysed the subsurface Chl-a concentration and physical properties such as ILD, MLD and BLT during the cyclone events using these measurements.

\section{Methodology}

The study is conducted for the $\mathrm{NIO}\left(3^{\circ}-25^{\circ} \mathrm{N}, 50^{\circ}-98^{\circ} \mathrm{E}\right)$ and the analyses are done separately for both oceanic regions in NIO; the BoB $\left(7^{\circ}-23^{\circ} \mathrm{N}\right.$, $\left.78^{\circ}-98^{\circ} \mathrm{E}\right)$ and $\mathrm{AS}\left(3^{\circ}-25^{\circ} \mathrm{N}, 50^{\circ}-78^{\circ} \mathrm{E}\right)$ basins. However, the analyses for
BoB are divided into four areas in accordance with the landfall of cyclones such as southwest $\left[7^{\circ}-15^{\circ} \mathrm{N}, 78^{\circ}-88^{\circ} \mathrm{E}\right]$, southeast $\left[7^{\circ}-15^{\circ} \mathrm{N}\right.$, $\left.88^{\circ}-98^{\circ} \mathrm{E}\right]$, northwest $\left[15^{\circ}-23^{\circ} \mathrm{N}, 78^{\circ}-88^{\circ} \mathrm{E}\right]$ and northeast $\left[15^{\circ}-23^{\circ} \mathrm{N}\right.$, $\left.88^{\circ}-98^{\circ} \mathrm{E}\right]$. Since the occurrence of cyclones over AS is infrequent as compared to BoB, we have not divided AS in separate regions for the analyses. The tracks of all cyclones considered in this study are shown in Fig. 1. We have analysed the cyclone events across all seasons. However, since the pre- and post-monsoon are the seasons of cyclones in $\mathrm{NIO}$, we further focus on these two seasons. The naming of NIO cyclones started from the year 2004 (by IMD) onwards. The cyclones are named according to the region of their occurrence and the order in which they occurred in the previous year (e.g. BOB01 in 2000 is the first cyclone that appeared in $B o B$ in 2000). In general, the naming is performed when the storm attains the wind speed of about 34 knots.

We examine the cyclone-induced phytoplankton bloom in $\mathrm{NIO}$ and at the cyclone track points. The Chl-a data are averaged for four periods: 5 days before the cyclone event, during, and just after the passage of the cyclone and again for the next 5 days. As the phytoplankton blooms are not frequent in the open ocean, a threshold of $0.2 \mathrm{mg} / \mathrm{m}^{3}$ is taken as the pre-cyclone background value in BoB/AS and the occurrence of Chl-a concentrations above $0.5 \mathrm{mg} / \mathrm{m}^{3}$ is considered as the bloom (Fig. 1). An analysis is done to check the ambient values in the open ocean waters and is presented in the figure for both basins. The pre-cyclone background value (Fig. 1) was selected by averaging the Chl-a by subtracting cyclone period and 5 days following the cyclone period from each of the basin. As shown in the figure, it is about $0.5 \mathrm{mg} / \mathrm{m}^{3}$ excluding the coastal blooms.

For each cyclone, a $4^{\circ} \times 4^{\circ}$ grid region where the $\mathrm{Chl}$-a concentrations are above $0.2 \mathrm{mg} / \mathrm{m}^{3}$ after passage of the cyclone along its track is chosen. The peak/maximum or bloom value is computed by averaging the $\mathrm{Chl}-\mathrm{a}$ in the $1^{\circ} \times 1^{\circ} \mathrm{grid}$ from the selected $4^{\circ} \times 4^{\circ}$ region. The temporal evolution of cyclones during five days before the cyclone, during the cyclone period and 10 days following the passage of cyclone is used to determine the lag in the occurrence of peak bloom associated with cyclones and thus to determine the percentage change in Chl-a. The change is calculated as

$$
\text { Change in Bloom }=\frac{\text { The peak value }- \text { the pre }- \text { cyclone value }}{\text { The pre }- \text { cyclone value }} \times \mathbf{1 0 0}
$$

That is, the change in bloom is computed by subtracting the pre-cyclone Chl-a value (the average computed in the selected $1^{\circ} \times 1^{\circ}$ grid for the precyclone 5 days) from the peak Chl-a observed after the cyclone (the average computed in the selected $1^{\circ} \times 1^{\circ}$ grid for the post-cyclone 5 days), and then divided by the same pre-cyclone value. The change in bloom with respect to the background value of $0.2 \mathrm{mg} / \mathrm{m}^{3}$ and the bloom threshold value of $0.5 \mathrm{mg} / \mathrm{m}^{3}$ are also estimated for comparisons, and are illustrated in Fig. 7 and Supplementary Fig. 6. 


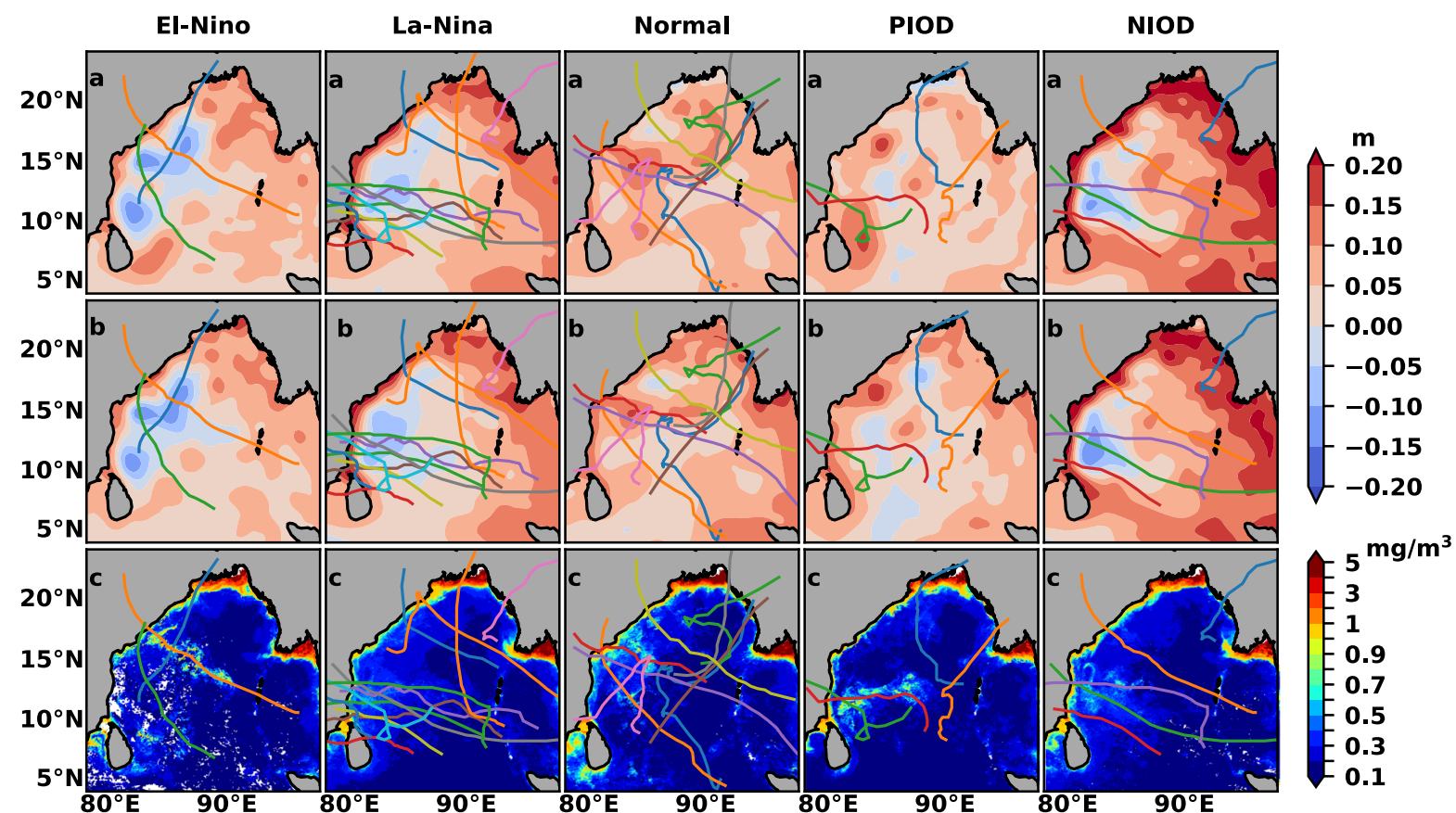

Fig. 8 The differences in Chl-a during El Niño, La Niña, normal, PIOD and NIOD years. The SSHA a 10-day before and $\mathbf{b}$ during the passage of cyclone) and Chl-a composite maps with respect to El Niño, La Niña, normal, PIOD and NIOD years in the BoB. The respective cyclone tracks are also shown.

The primary mechanism for the phytoplankton bloom during passage of cyclones is the wind driven upwelling. The EPV is the measure of the upwelling velocity and is calculated at the cyclone track points as the cyclone reaches its peak intensity. The ERA5 $10 \mathrm{~m}$ daily wind data of $12.5 \times$ $12.5 \mathrm{~km}$ resolution are used for computing the EPV associated with TCs, where positive values of EPV suggest upwelling.

The EPV is estimated as EPV $=\frac{1}{\rho f} \nabla x \tau$

in $\mathrm{m} / \mathrm{s}$, where $\nabla x \tau$ is wind stress, $\rho$ is the density of sea water $\left(1029 \mathrm{~kg} / \mathrm{m}^{3}\right)$ and $f$ is the Coriolis parameter.

The TS has a great influence on cyclone-induced bloom and is calculated along the cyclone track points ${ }^{63}$. The TS along the track of cyclones is estimated using Haversine's distance formula, which gives the distance between each track points. This is calculated as:

$a=\sin ^{2}(\Delta \Phi / 2)+\cos \left(\Phi_{2}\right) x \cos \left(\Phi_{2}\right) x \sin ^{2}(\Delta \lambda / 2)$

$c=2 \operatorname{atan} 2(\sqrt{ } a, \sqrt{ }(1-a))$

$d=R c$

where, $\Phi$-Latitude and $\lambda$-Longitude, and $R$ is radius of earth, i.e. $6371 \mathrm{~km} \Delta \Phi=\Phi_{2}-\Phi_{1}$ (Difference between latitude) and $\Delta \lambda=\lambda_{2}-\lambda_{1}$ (Difference between longitude)

and $d$ is the distance between the track points, and is then used to obtain the TS in every $6 \mathrm{~h}$ interval along the track points and the unit is $\mathrm{m} /$ s.

\section{DATA AVAILABILITY}

Daily Chl-a data are available on: https://www.oceancolour.org/thredds/catalog-cci. html, the track data on http://www.usno.navy.mil/JTWC/best-track-archive. The $10 \mathrm{~m}$ wind data on https://cds.climate.copernicus.eu/cdsapp\#!/dataset/reanalysis-era5single-levels?tab=form. The Ocean Niño Index: https://origin.cpc.ncep.noaa.gov/ products/analysis_monitoring/ensostuff/ONI_v5.php, the Dipole Mode Index: https:// psl.noaa.gov/gcos_wgsp/Timeseries/Data/dmi.had.long.data, and the altimeter products distributed by E.U. Copernicus Marine Service Information (CMEMS): https:// cmems-cas.cls.fr/ are found in the given websites.
Received: 21 October 2020; Accepted: 23 January 2021;

Published online: 24 February 2021

\section{REFERENCES}

1. Alam, M. M., Hossain, M. A. \& Shafee, S. Frequency of Bay of Bengal cyclonic storms and depressions crossing different coastal zones. Int. J. Climatol. 23, 1119-1125 (2003).

2. Sengupta, D., Goddalehundi, B. R. \& Anitha, D. S. Cyclone-induced mixing does not cool SST in the post-monsoon north Bay of Bengal. Atmos. Sci. Lett. 9, 1-6 (2008).

3. Dai, A., Qian, T., Trenberth, K. E. \& Milliman, J. D. Changes in continental freshwater discharge from 1948 to 2004. J. Clim. 22, 2773-2792 (2009).

4. Fekete, B. M., Vörösmarty, C. J. \& Grabs, W. High-resolution fields of global runoff combining observed river discharge and simulated water balances. Glob. Biogeochem. Cycles 16, 15-1-15-10 (2002).

5. Han, W. \& McCreary, J. P. Modeling salinity distributions in the Indian Ocean. J. Geophys. Res. Ocean. 106, 859-877 (2001).

6. Prasad, T. G. \& Ikeda, M. A numerical study of the seasonal variability of Arabian Sea high-salinity water. J. Geophys. Res. Ocean. 107, 18-1-18-12 (2002).

7. Prasad, T. G. Annual and seasonal mean buoyancy fluxes for the tropical Indian Ocean. Curr. Sci. 73, 667-674 (1997).

8. Subramanian, V. Sediment load of Indian rivers. Curr. Sci. 64, 928-930 (1993).

9. Das, B. K. et al. Influence of river discharge and tides on the summertime discontinuity of Western Boundary Current in the Bay of Bengal. J. Phys. Oceanogr. 50, 3513-3528 (2020).

10. Gopalakrishna, V. V., Murty, V. S. N., Sengupta, D., Shenoy, S. \& Araligidad, N. Upper ocean stratification and circulation in the northern Bay of Bengal during southwest monsoon of 1991. Cont. Shelf Res. 22, 791-802 (2002).

11. Balaguru, K. et al. Ocean barrier layers' effect on tropical cyclone intensification. Proc. Natl. Acad. Sci. USA 109, 14343-14347 (2012).

12. Sreenivas, P., Gnanaseelan, C. \& Prasad, K. V. S. R. Influence of El Niño and Indian Ocean Dipole on sea level variability in the Bay of Bengal. Glob. Planet. Change 80, 215-225 (2012).

13. Qasim, S. Z. Biological productivity of the Indian Ocean. Indian J. Geo Mar. Sci. 06, 122-137 (1977).

14. Prasanna Kumar, S. et al. Why is the Bay of Bengal less productive during summer monsoon compared to the Arabian Sea? Geophys. Res. Lett. 29, 88-1-88-4 (2002).

15. Lü, H. et al. A case study of a phytoplankton bloom triggered by a tropical cyclone and cyclonic eddies. PLOS ONE 15, e0230394 (2020). 
16. Eppley, R. W. \& Renger, E. H. Nanomolar increase in surface layer nitrate concentration following a small wind event. Deep Sea Res. Part A Oceanogr. Res. Pap. 35, 1119-1125 (1988).

17. Byju, P. \& Prasanna Kumar, S. Physical and biological response of the Arabian Sea to tropical cyclone Phyan and its implications. Mar. Environ. Res. 71, 325-330 (2011).

18. Vinayachandran, P. N. \& Mathew, S. Phytoplankton bloom in the Bay of Bengal during the northeast monsoon and its intensification by cyclones. Geophys. Res. Lett. 30, 26-1-26-4 (2003).

19. Girishkumar, M. S. \& Ravichandran, M. The influences of ENSO on tropical cyclone activity in the Bay of Bengal during October-December. J. Geophys. Res. Ocean. 117, C02033 (2012).

20. Sengupta, D., Bharath Raj, G. N. \& Shenoi, S. S. C. Surface freshwater from Bay of Bengal runoff and Indonesian Throughflow in the tropical Indian Ocean. Geophys. Res. Lett. 33, L22609 (2006).

21. Vidya, P. J., Das, S. \& Murali, M. Contrasting Chl-a responses to the tropical cyclones Thane and Phailin in the Bay of Bengal. J. Mar. Syst. 165, 103-114 (2017).

22. Dahal, D., Liu, S. \& Oeding, J. The carbon cycle and hurricanes in the United States between 1900 and 2011. Sci. Rep. 4, 5197 (2014).

23. Nayak, S. R., Sarangi, R. K. \& Rajawat, A. S. Application of IRS-P4 OCM data to study the impact of cyclone on coastal environment of Orissa. Curr. Sci. 80, 1208-1213 (2001).

24. Patra, P. K., Kumar, M. D., Mahowald, N. \& Sarma, V. V. S. S. Atmospheric deposition and surface stratification as controls of contrasting chlorophyll abundance in the North Indian Ocean. J. Geophys. Res. Ocean. 112, C05029 (2007).

25. Sarangi, R. K., Nayak, S. \& Panigraphy, R. C. Monthly variability of chlorophyll and associated physical parameters in the southwest Bay of Bengal water using remote sensing data. Indian J. Mar. Sci. 37, 256-266 (2008).

26. Rao, K. H., Smitha, A. \& Ali, M. M. A study on cyclone induced productivity in south-western Bay of Bengal during November-December 2000 using MODIS (SST and chlorophyll-a) and altimeter sea surface height observations. Indian J. Mar. Sci. 35, 153-160 (2006).

27. Chacko, N. Chlorophyll bloom in response to tropical cyclone Hudhud in the Bay of Bengal: Bio-Argo subsurface observations. Deep. Res. Part I Oceanogr. Res. Pap. 124, 66-72 (2017).

28. Chacko, N. Differential chlorophyll blooms induced by tropical cyclones and their relation to cyclone characteristics and ocean pre-conditions in the Indian Ocean. J. Earth Syst. Sci. 128, 177 (2019).

29. Subrahmanyam, B., Rao, K. H., Srinivasa Rao, N., Murty, V. S. N. \& Sharp, R. J. Influence of a tropical cyclone on chlorophyll-a concentration in the Arabian Sea. Geophys. Res. Lett. 29, 22-1-22-4 (2002).

30. Chakraborty, K. et al. Modeling the enhancement of sea surface chlorophyll concentration during the cyclonic events in the Arabian Sea. J. Sea Res. 140, 22-31 (2018)

31. Pan, J., Huang, L., Devlin, A. T. \& Lin, H. Quantification of typhoon-induced Phytoplankton blooms using satellite multi-sensor data. Remote Sens. 10, 318 (2018).

32. Anandh, T. S. et al. A Comparative analysis of the Bay of Bengal Ocean state using standalone and coupled numerical models. Asia Pacific J. Atmos. Sci. 56 (2020). https://doi.org/10.1007/s13143-020-00197-z.

33. Krishnan, R. et al. Assessment of Climate Change over the Indian Region: A Report of the Ministry of Earth Sciences (MoES), Government of India (Springer Singapore, 2020).

34. Kuttippurath, J. et al. Observed rainfall changes in the past century (1901-2019) over the wettest place on the Earth. Environ. Res. Lett. 16, 024018 (2020)

35. McBride, J. L. Tropical cyclone formation. Glob. Perspect. Trop. cyclones, WMO Tech. Doc. 693, 63-105 (1995).

36. Camargo, S. J., Robertson, A. W., Gaffney, S. J., Smyth, P. \& Ghil, M. Cluster analysis of typhoon tracks. Part II: Large-scale circulation and ENSO. J. Clim. 20, 3654-3676 (2007).

37. Kikuchi, K. \& Wang, B. Formation of tropical cyclones in the Northern Indian ocean associated with two types of tropical intraseasonal oscillation modes. J. Meteorol. Soc. Jpn. 88, 475-496 (2010).

38. Frank, W. M. Tropical cyclone formation. Glob. View Trop. Cyclones, R. L. Elsberry, Ed., U.S.Office of Naval Research Monterey, CA, 53-90 (1987).

39. Akter, N. \& Tsuboki, K. Role of synoptic-scale forcing in cyclogenesis over the Bay of Bengal. Clim. Dyn. 43, 2651-2662 (2014).

40. Gierach, M. M. \& Subrahmanyam, B. Biophysical responses of the upper ocean to major Gulf of Mexico hurricanes in 2005. J. Geophys. Res. Ocean. 113, C04029 (2008).

41. Gomes, H. R., Goes, J. I. \& Saino, T. Influence of physical processes and freshwater discharge on the seasonality of phytoplankton regime in the Bay of Bengal. Cont Shelf Res. 20, 313-330 (2000).

42. Singh, O. P., Ali Khan, T. M. \& Rahman, M. S. Changes in the frequency of tropical cyclones over the North Indian Ocean. Meteorol. Atmos. Phys. 75, 11-20 (2000).
43. Girishkumar, M. S. et al. Quantifying tropical cyclone's effect on the biogeochemical processes using profiling float observations in the Bay of Bengal. J. Geophys. Res. Ocean. 124, 1945-1963 (2019).

44. Price, J. F. Upper ocean response to a hurricane. J. Phys. Oceanogr. 11, 153-175 (1981).

45. Pothapakula, P. K. et al. Observational perspective of SST changes during life cycle of tropical cyclones over Bay of Bengal. Nat. Hazards 88, 1769-1787 (2017).

46. McPhaden, M. J. et al. Ocean-atmosphere interactions during cyclone nargis. EOS 90, 53-60 (2009)

47. Subbaramayya, I. \& Rao, M. S. Cyclone climatology of North Indian Ocean. Short Communication. Indian J. Mar. Sci. 10, 366-368 (1981).

48. Tummala, S. K. Phytoplankton bloom due to Cyclone Sidr in the central Bay of Bengal. J. Appl. Remote Sens. 3, 033547 (2009).

49. Maneesha, K. et al. Meso-scale atmospheric events promote phytoplankton blooms in the coastal Bay of Bengal. J. Earth Syst. Sci. 120, 773-782 (2011).

50. Jaimes, B., Shay, L. K. \& Halliwell, G. R. The response of quasigeostrophic oceanic vortices to tropical cyclone forcing. J. Phys. Oceanogr. 41, 1965-1985 (2011).

51. Vinayachandran, P. N., Murty, V. S. N. \& Babu, V. R. Observations of barrier layer formation in the Bay of Bengal during summer monsoon. J. Geophys. Res. Ocean. 107, 19-1-19-9 (2002).

52. Madhu, N. V. et al. Enhanced biological production off Chennai triggered by October 1999 super cyclone (Orissa). Curr. Sci. 82, 1472-1479 (2002).

53. Prasanna Kumar, S. et al. Physical control of primary productivity on a seasonal scale in central and eastern Arabian Sea. Proc. Indian Acad. Sci. Earth Planet. Sci. 109, 433-441 (2000).

54. Bhattathiri, P. M. A. et al. Phytoplankton production and chlorophyll distribution in the eastern and central Arabian Sea in 1994-1995. Curr. Sci. 71, 857-862 (1996)

55. Ho, C. H., Kim, J. H., Jeong, J. H., Kim, H. S. \& Chen, D. Variation of tropical cyclone activity in the South Indian Ocean: El Niño-Southern Oscillation and MaddenJulian Oscillation effects. J. Geophys. Res. Atmos. 111, D22101 (2006).

56. Kuleshov, Y., Qi, L., Fawcett, R. \& Jones, D. On tropical cyclone activity in the Southern Hemisphere: trends and the ENSO connection. Geophys. Res. Lett. 35, L14S08 (2008).

57. Raoult, B. \& Correa, R. in Cloud Computing in Ocean and Atmospheric Sciences, Acdemic Press, 121-135 (2016). https://doi.org/10.1016/C2014-0-04015-4.

58. Wang, L. Y., Hu, H. B., Yang, X. Q. \& Ren, X. J. Atmospheric eddy anomalies associated with the wintertime North Pacific subtropical front strength and their influences on the seasonal-mean atmosphere. Sci. China Earth Sci. 59, 2022-2036 (2016).

59. Prasanna Kumar, S. et al. Are eddies nature's trigger to enhance biological productivity in the Bay of Bengal? Geophys. Res. Lett. 31, L07309 (2004).

60. Falkowski, P. G., Ziemann, D., Kolber, Z. \& Bienfang, P. K. Role of eddy pumping in enhancing primary production in the ocean. Nature 352, 55-58 (1991).

61. Shang, S. et al. Changes of temperature and bio-optical properties in the South China Sea in response to Typhoon Lingling, 2001. Geophys. Res. Lett. 35, L10602 (2008).

62. Ravichandran, M., Girishkumar, M. S. \& Riser, S. Observed variability of chlorophyll-a using Argo profiling floats in the southeastern Arabian Sea. Deep. Res. Part I Oceanogr. Res. Pap. 65, 15-25 (2012).

63. Mei, W., Pasquero, C. \& Primeau, F. The effect of translation speed upon the intensity of tropical cyclones over the tropical ocean. Geophys. Res. Lett. 39 L07801 (2012).

\section{ACKNOWLEDGEMENTS}

We thank Head CORAL, the Director of Indian Institute of Technology Kharagpur (IIT Kgp), Sponsored Research and Industrial Consultancy of IIT Kgp. S.N. and J.K gratefully acknowledge the support from the Indian National Centre for Ocean Information Services (INCOIS), Ministry of Earth Sciences, Hyderabad. K.C. gratefully acknowledges the unconditional support of INCOIS in executing this work. M.V.M acknowledge his gratitude to the National Institute of Ocean Technology Chennai, Ministry of Earth Sciences, India. J.K. thank NIOT Chennai and INCOIS Hyderabad for the Argo float data, and the Ocean Environmental Panel (OEP) of Naval Research Board, Defense Research and Development Organisation (DRDO) for facilitating this research. We thank Ocean Colour Climate Change Initiative (OC-CCI) for providing them with the daily chlorophyll-a data, Joint Typhoon Warning Centre (JTWC) and Regional Specialized Meteorological Centre for Tropical Cyclones over North Indian Ocean, India Meteorological Department (IMD) for the cyclone track data and European Centre for Medium Range Weather Forecast (ECMWF) for the wind data. This is INCOIS contribution number 402.

\section{AUTHOR CONTRIBUTIONS}

J.K.: Conceptualization, Methodology, Software, Validation, Formal analysis, Investigation, Resources, Data Curation, Writing-Original Draft, Writing-Review and Editing 
Visualization, Supervision, Project administration, Funding acquisition. S.N.: Methodology, Software, Formal analysis, Investigation, Data Curation, Writing-Original Draft, Writing-Review and Editing, Visualization. M.V.M.: Methodology, Software, Investigation, Resources. K.C.: Review and Editing, Methodology, Software, Investigation, Resources.

\section{COMPETING INTERESTS}

The authors declare no competing interests.

\section{ADDITIONAL INFORMATION}

Supplementary information The online version contains supplementary material available at https://doi.org/10.1038/s41612-021-00166-x.

Correspondence and requests for materials should be addressed to J.K.

Reprints and permission information is available at http://www.nature.com/ reprints
Publisher's note Springer Nature remains neutral with regard to jurisdictional claims in published maps and institutional affiliations. (c) (i) Open Access This article is licensed under a Creative Commons Attribution 4.0 International License, which permits use, sharing, adaptation, distribution and reproduction in any medium or format, as long as you give appropriate credit to the original author(s) and the source, provide a link to the Creative Commons license, and indicate if changes were made. The images or other third party material in this article are included in the article's Creative Commons license, unless indicated otherwise in a credit line to the material. If material is not included in the article's Creative Commons license and your intended use is not permitted by statutory regulation or exceeds the permitted use, you will need to obtain permission directly from the copyright holder. To view a copy of this license, visit http://creativecommons. org/licenses/by/4.0/.

(c) The Author(s) 2021 